\title{
The Factors Correlating to the Usage of Long-Term Contraception Method (MKJP) Especially IUD in the Domain of Society Health Center Simpang Baru Pekanbaru City
}

\author{
Sri Wardani and Eliza Fitria
}

Public Health Program, STIKes Tengku Maharatu, Indonesia

\section{Abstract}

Looking at the development of Long Term Contraception Method (henceforth; MKJP) usage during some periods, apparently the usage of IUD continues to decrease. The purpose of this research is to know the correlation between knowledge, couple agreement, culture, and the usage of MKJP especially IUD. The type of this research was quantitative research, with cross sectional design. The total population of MKJP users were 621 people. The samples taken were 243, the technique of taking the samples

Corresponding Author:

Sri Wardani

sriwardani44@gmail.com

Received: 18 January 2019 Accepted: 26 February 2019 Published: 12 March 2019

Publishing services provided by Knowledge E

(c) Sri Wardani and Eliza Fitria. This article is distributed under the terms of the Creative Commons Attribution License, which permits unrestricted use and redistribution provided that the original author and source are credited.

Selection and Peer-review under the responsibility of the 1st PANIHC Conference Committee. were through systematic random sampling. The result of chi-square test obtained that there is correlation between knowledge and the usage of MKJP especially IUD with the score of $p$-value $=0,00$. There is correlation between the spouse support and the usage of MKJP especially IUD with the score of $p$-value $=0,013$. The score of OR 5,15. There is correlation between the culture and the usage of MKJP especially IUD with the score of $p$-value $=0,019$, the score of OR 5,41 . The most dominant variable correlating to the usage of MKJP especially IUD is the spouse support. It means respondents who have negative support from their spouses have chance to not using MKJP especially IUD. It is expected to the policy maker to create programs as an effort to improve the knowledge of the society through socialization, leaflet, and other media, activating the agent in the field, synergy across sector, public figure, until giving understanding, mindset, trust, capability, and spouse support which results in creating the culture of using MKJP especially IUD.

Keywords: MKJP, IUD, knowledge, spouse support, culture

\section{Introduction}

Long Term Contraception Method (MKJP) which consists of Intra Uterine Devise (IUD), implant, man operative medic (MOP), and woman operative medic (MOW) are very effective to be used. Looking at the development of MKJP usage for some periods, apparently the usage of IUD continues to decrease, meanwhile the achievement of MOP, MOW, are relatively the same, and implant achievement experiences fluctuations. IUD is one 
of device entered and kept in the uterine cavity, with the purpose to prevent or to nest the pregnancy in a long time period. The data of Indonesia Health Demography Survey (SDKI) shows the pattern of MKJP contraception usage especially IUD tends to decrease such as 13,3\% (SDKI, 1991), 10,3\% (SDKI, 1997), 6,2\% (SDKI, 2002-2003), 4,9\% (SDKI, 2007), 4\% (SDKI, 2012-2013) [1]. The usage of short term contraception precisely develop especially the usage of injection contraception. The usage of short term contraception has bigger failure risk compared to long term contraception. The advantages of using IUD is very effective, safe, and of course reversible for women, especially those who are infected by sexually transmitted disease (PMS) and has experience of giving birth, only needs once installation for a long period of time and the cost is relatively cheap, safe because it does not have effect towards the body overall, it does not affect breast milk production, and the fertility can come back soon after IUD is released. Pekanbaru City is the capital city of Riau Province and the number of Fertile Age Spouse (PUS) counted until December 2014 in the amount of 174.726 people. The participants of active Family Planning (henceforth; KB) program in the amount of 129.959 (74,37\%). MKJP achievement for Pekanbaru City is the in the amount of 21.988 (16,9\%), while the usage of short term contraception is higher in the amount of $107.971(83,08 \%)$, and the achievement of IUD usage in the amount of 11.861 (9\%) [2].

\section{Method and Research Instruments}

The type of this research was a quantitative research with cross sectional design. The population in this research were all all KB acceptors who used MKJP at the domain of Simpang Baru Society Health Center in the amount of 621 people. The samples were in the amount of 243 [2].

The technique of taking the samples was by using systematic random sampling method. The instruments used in this research were knowledge questionnaires, spouse support, and culture. Data processing was by using computer, through four stages; they are: editing, coding, processing, and cleaning. The collected data then analyzed with univariate, bivariate, and multivariate using chi square test.

\section{Results}




\subsection{Univariate analysis}

Univariate analysis was used to described the distribution and frequency of dependent variable (the usage of MKJP especially IUD) and independent variables (knowledge, spouse support, and culture), can be seen in the table below:

TABLE 1: The Frequency Distribution based on Knowledge, Spouse Support, Culture, and The Usage of MKJP especially IUD at Society Health Center Simpang Baru in 2018.

\begin{tabular}{|c|c|c|c|}
\hline No & Variables & $\mathbf{N}$ & Percentage \% \\
\hline \multirow[t]{4}{*}{1} & \multicolumn{3}{|c|}{ Dependent Variable } \\
\hline & \multicolumn{3}{|c|}{ The Usage of MKJP especially IUD } \\
\hline & 1) $\mathrm{No}$ & 231 & $95,1 \%$ \\
\hline & 2) Yes & 12 & $4,9 \%$ \\
\hline \multirow[t]{12}{*}{2} & \multicolumn{3}{|c|}{ Independent Variables } \\
\hline & \multicolumn{3}{|l|}{ a. Knowledge } \\
\hline & 1) Less & 168 & $69,1 \%$ \\
\hline & 2) Sufficient & 11 & $4,5 \%$ \\
\hline & 3) Good & 64 & $26,3 \%$ \\
\hline & \multicolumn{3}{|c|}{ b. Spouse Support } \\
\hline & 1) Negative & 149 & $61,3 \%$ \\
\hline & 2) Positive & 94 & $38,7 \%$ \\
\hline & \multicolumn{3}{|l|}{ c. Culture } \\
\hline & 1) $\mathrm{No}$ & 122 & $50,2 \%$ \\
\hline & 2) Yes & 121 & $49,8 \%$ \\
\hline & Total & 243 & 100 \\
\hline
\end{tabular}

Based on the table above, out of 243 respondents, in fact 231 people $(95,1 \%)$ do not use MKJP especially IUD and 12 people (4.9\%) use it. For knowledge 168 people (69,1\%) have less knowledge, 11 people (4.5\%) have sufficient knowledge, and 64 people (26,3\%) have good knowledge. For the spouse support 149 people (61.3\%) give negative support and 94 people (38.7\%) give positive support. For the culture 122 people (50.2\%) are not affected by the culture, and 121 people (49.8\%) are affected by the culture.

\subsection{Bivariate analysis}

\subsubsection{The correlation between knowledge and the usage of MKJP especially IUD}

To see the correlation between independent variables (knowledge, spouse support, and culture) and dependent variable (the usage of MKJP especially IUD) then bivariate 
analysis was conducted, and statistical test used was chi-square with reliability limitation $95 \%$ until $\alpha=0.05$ then obtained the results as follows:

TABLE 2: The Correlation Between Knowledge and The Usage of MKJP especially IUD at Society Health Center Simpang Baru in 2018.

Knowledge
Less
Sufficient
Good
Total

\begin{tabular}{|c|c|c|c|}
\hline \multicolumn{3}{|c|}{ The Usage of MKJP especially IUD } \\
\hline \multicolumn{3}{|c|}{ No } & \multicolumn{3}{|c|}{ Yes } \\
\hline $\mathbf{n}$ & $\%$ & $\mathbf{N}$ & $\%$ \\
\hline 166 & 98,8 & 2 & 1,2 \\
\hline 7 & 63,6 & 4 & 36,4 \\
\hline 58 & 90,6 & 6 & 9,4 \\
\hline 231 & 95,1 & 4,9 & 12 \\
\hline
\end{tabular}

\begin{tabular}{|c|c|c|}
\hline \multicolumn{2}{|c|}{ Total } & p value \\
\hline $\mathbf{N}$ & $\%$ & \\
\hline 168 & 100 & 0.00 \\
\hline 11 & 100 & \\
\hline 64 & 100 & \\
\hline 243 & 100 & \\
\hline
\end{tabular}

Based on the table above, the result of analysis shows that out of 168 respondents have less knowledge, in fact 166 respondents $(98,8 \%$ ) do not use MKJP especially IUD. Out of 11 respondents having sufficient knowledge, in fact 7 respondents (63.6\%) do not use MKJP especially IUD. Out of 64 respondents having good knowledge, in fact 58 respondents $(90,6 \%)$ do not use MKJP especially IUD. From the result of statistics chisquare test obtained $p=0.00<0.05$, it means there is correlation between knowledge and the usage of MKJP especially IUD at Society Health Center Simpang Baru.

\subsubsection{The correlation between spouse support and the usage of MKJP especially IUD}

TABLE 3: The Correlation Between Spouse Support and The Usage of MKJP especially IUD at Society Health Center Simpang Baru in 2018.

\begin{tabular}{|c|c|c|c|c|c|c|c|c|}
\hline \multirow[t]{3}{*}{ Spouse Support } & \multicolumn{4}{|c|}{ The Usage of MKJP especially IUD } & \multicolumn{2}{|c|}{ Total } & \multirow[t]{3}{*}{ p value } & \multirow[t]{3}{*}{ OR } \\
\hline & \multicolumn{2}{|c|}{ No } & \multicolumn{2}{|c|}{ Yes } & & & & \\
\hline & $\mathbf{n}$ & $\%$ & $\mathbf{N}$ & $\%$ & $\mathbf{N}$ & $\%$ & & \\
\hline Negative & 146 & 98 & 3 & 2 & 149 & 100 & 0.013 & 5,15 \\
\hline Positive & 85 & 90,4 & 9 & 9,6 & 94 & 100 & & \\
\hline Total & 231 & 95,1 & 12 & 4,9 & 243 & 100 & & \\
\hline
\end{tabular}

Based on the table above, the analysis results show that out of 149 respondents having negative support from their spouse, in fact 146 respondents (98\%) do not use MKJP especially IUD. Out of 94 respondents having positive attitude, in fact 85 respondents (20\%) do not use MKJP especially IUD. The results of statitistics chi-square test obtained $p=0.013<0.05$, which means there is correlation between spouse support and the usage of MKJP especially IUD at society health center Simpang Baru. It also obtained the score of $O R$ in the amount of 5.15 which means respondents who get negative support 
from their family have opportunity 5.15 times higher to not using MKJP especially IUD compared to the spouse with positive support from their spouse.

\subsubsection{The correlation between culture and the usage of MKJP especially IUD}

TABLE 4: The Correlation Between Culture and The Usage of MKJP especially IUD at Society Health Center Simpang Baru in 2018.

\begin{tabular}{|c|c|c|c|c|c|c|c|c|}
\hline \multirow[t]{3}{*}{ Culture } & \multicolumn{4}{|c|}{ The Usage of MKJP especially IUD } & \multicolumn{2}{|c|}{ Total } & \multirow[t]{3}{*}{$p$ value } & \multirow[t]{3}{*}{ OR } \\
\hline & \multicolumn{2}{|c|}{ No } & \multicolumn{2}{|c|}{ Yes } & & & & \\
\hline & $\mathbf{n}$ & $\%$ & $\mathbf{n}$ & $\%$ & $\mathbf{N}$ & $\%$ & & \\
\hline No & 120 & 98,4 & 2 & 1,6 & 122 & 100 & 0.019 & 5,41 \\
\hline Yes & 111 & 91,7 & 10 & 8,3 & 121 & 100 & & \\
\hline Total & 231 & 95,1 & 12 & 4,9 & 243 & 100 & & \\
\hline
\end{tabular}

Based on the table above, the results of analysis show that out of 122 respondents having bad culture, in fact 120 respondents (98.4\%) do not use MKJP especially IUD. Out of 121 respondents having good culture, in fact 111 respondents $(91.7 \%)$ do not use MKJP especially IUD. The result of statistical chi-square test obtained $p=0.013<0.05$, which means there is correlation between culture and the usage of MKJP especially IUD at society health center Simpang Baru. It also obtained the score of OR in the amount of 5.41 which means respondents having bad culture have a change 5.41 times higher to not using MKJP especially IUD compared to those with good culture.

\subsection{Multivariate analysis to see the most dominant factor towards the usage of MKJP especially IUD}

1. The first step is model candidate selection

In determining the most dominant factor towards the usage of MKJP especially IUD at society health center Simpang Baru, then multivariate analysis was conducted by making the modelling. Modelling used is multiple logistics regression with the reason the research variable is categorical. The first step in this modelling is variable selection, determining the variable which can be put into the model candidate is the variable with $p$-value $<0.25$. The result of variable selection is seen at table 5 below.

Based on the selection result above, then all variables are included into the multivariate model and form the initial model as follows: 
TABLE 5: The Selection Result of Model Candidate Variable.

\begin{tabular}{|l|l|c|c|}
\hline No & Variables & p value & Description \\
\hline 1. & Knowledge & 0.00 & Candidate \\
\hline 2. & Spouse Support & 0.013 & Candidate \\
\hline 3. & Culture & 0.019 & Candidate \\
\hline
\end{tabular}

TABLE 6: The Initial Multivariate Model of Dominant Variable Towards The Usage of MKJP especially IUD at Society Health Center Simpang Baru.

\begin{tabular}{|l|l|c|c|c|c|c|c|c|}
\hline \multicolumn{10}{|c|}{ Variables in the Equation } \\
\hline Step $1^{a}$ & \multicolumn{10}{|c|}{ B } & S.E. & Wald & Df & Sig. & Exp(B) \\
\hline & Knowledge & 0,914 & 0,342 & 7,153 & 1 & .007 & 2,494 \\
\hline & Spouse Support & 1,830 & 0,709 & 6,659 & 1 & .010 & 6,233 \\
\hline & Culture & 1,822 & 0,810 & 5,053 & 1 & .025 & 6,184 \\
\hline & Constant & $-10,618$ & 2,184 & 23,645 & 1 & .000 & .000 \\
\hline
\end{tabular}

Based on the table above, there is not variable with $p$-value $>0.05$ and there is variable elimination from the model which means all variables affect the usage of MKJP especially IUD, next interaction test was conducted to determine if among those independent variables make interaction that creates a new variable. A variable can be said having interaction if $\mathrm{p}$-value $<0.05$, with the result of interaction test as follows:

TABLE 7: Interaction Test Results.

\begin{tabular}{|c|c|c|c|c|c|c|c|}
\hline \multicolumn{8}{|c|}{ Variables in the Equation } \\
\hline & & $\mathrm{B}$ & S.E. & Wald & Df & Sig. & $\operatorname{Exp}(B)$ \\
\hline \multirow[t]{6}{*}{ Step $1^{a}$} & Knowledge & 0,914 & 0,342 & 7,153 & 1 & .007 & 2,494 \\
\hline & Spouse Support & 1,830 & 0,709 & 6,659 & 1 & .010 & 6,233 \\
\hline & Culture & 1,822 & 0,810 & 5,053 & 1 & .025 & 6,184 \\
\hline & $\begin{array}{l}\text { Knowledge by the } \\
\text { spouse support }\end{array}$ & $-0,760$ & 0,698 & & 1 & 0,403 & 0,468 \\
\hline & Knowledge by culture & $-0,662$ & 0,449 & & 1 & 0,503 & 0,516 \\
\hline & $\begin{array}{l}\text { Spouse support by } \\
\text { culture }\end{array}$ & $-16,634$ & 0,000 & & 1 & 0,997 & 0,000 \\
\hline
\end{tabular}

Based on the table above, there is no interaction because the variable which is expected to have interaction with $\mathrm{p}$ value $>0.05$, next formed the final model with results as follows:

Based on the table above, it can be concluded that the most dominant variable towards the usage of MKJP especially IUD at Society Health Center Simpang Baru is the spouse support with OR in the amount of 6.23 which means respondents who have negative support from their spouse have a chance to not using MKJP especially IUD in the amount of 6.23 kali higher after controlled by the respondents' knowledge and culture where they reside. 
TABLE 8: The Final Model of Multivariate Modelling Dominant Variable Towards The Usage of MKJP especially IUD at Society Health Center Simpang Baru.

\begin{tabular}{|c|c|c|c|c|c|c|c|}
\hline \multicolumn{8}{|c|}{ Variables in the Equation } \\
\hline & & $\mathrm{B}$ & S.E. & Wald & Df & Sig. & $\operatorname{Exp}(B)$ \\
\hline \multirow[t]{4}{*}{ Step $1^{a}$} & Knowledge & 0,914 & 0,342 & 7,153 & 1 & .007 & 2,494 \\
\hline & Spouse Support & 1,830 & 0,709 & 6,659 & 1 & .010 & 6,233 \\
\hline & Culture & 1,822 & 0,810 & 5,053 & 1 & .025 & 6,184 \\
\hline & Constant & $-10,618$ & 2,184 & 23,645 & 1 & .000 & .000 \\
\hline
\end{tabular}

\section{Discussion}

\subsection{The interpretation of the research results}

\subsubsection{The correlation between knowledge and the usage of MKJP especially IUD}

The research results find out that out of 168 respondents having less knowledge, in fact 166 respondents (98.8\%) do not use MKJP especially IUD. Out of 11 respondents having sufficient knowledge, in fact 7 respondents (63.6\%) do not use MKJP especially IUD. Out of 64 respondents having good knowledge, in fact 58 respondents (90.6\%) do not use MKJP especially IUD. From the results of statistical chi-square test, obtained $p=0.0<0.05$, which means there is correlation between knowledge and the usage of MKJP especially IUD at society health center Simpang Baru.

Knowledge is the result of knowing something and this occurs after conducting sensing towards certain object, with the knowledge stages such as: know, comprehension, application, analysis, synthesis, and evaluation [3]. This assessment based on one criteria determined by themselves, or using the available criteria.

This research is in line with a research that stated there is correlation between knowledge and the contraception tool in the womb (AKDR) for KB acceptor at the domain of Society Health Center Jailolo [4]. Another research stated that there is correlation between knowledge and KB participation by PUS at the domain of Society Health Center Tambang, Kampar Regency [5].

According to the researchers' assumption, information related to MKJP especially IUD must be complete and is an important aspect in the socialization, leaflet, or other media and creating the agent in the field who come dor to dor giving information and inviting the fertile age spouses having the knowledge, understand, and apply something they know with the real condition, analyze, and evaluate the contraception tool. Some will choose KB IUD if they understand and know a lot about it. 


\subsubsection{The correlation between spouse support and the usage of MKJP especially IUD}

The research results found out that out of 149 respondents having negative support from their spouse, in fact 146 respondents (98\%) do not use MKJP especially IUD. Out of 94 respondents having positive support from their spouse, in fact 85 respondents (20\%) do not use MKJP especially IUD. The results of statistical chi-square test obtained $p=0.013$ $<0.05$, it means there is correlation between spouse support and the usage of MKJP especially IUD at Society Health Center Simpang Baru. It also obtained the score of OR in the amount of 5.15, which means respondents with negative support from their spouse have a change 5.15 times higher to not using MKJP especially IUD compared to those with positive support from their spouse.

The spouse agreement in KB program and reproduction health are the factors that play role in creating the responsibility husband in $\mathrm{KB}$ and reproduction health [2]. This participation can be embodied if various information related to it provided completely, let alone we know that the low participation of husband in KB and reproduction health are still limited in the information especially husband and wife.

A research stated that husband's support is very necessary in using AKDR, because before the usage of AKDR, there must be written agreement on the informed consent from the spousenn [6]. Based on that information and explanation, then the medical treatment will be conducted. The installation of AKDR needs cooperation from the husband because of the fear on the yarn will disturb when they have the sex [6]. The spouse agreement which supports 0.356 times have bigger chance in choosing AKDR compared to the spouses that do not support.

According to the researcher's assumption, the spouse support in the usage of MKJP especially IUD can be improved through effective communication among the spouses. The wife as the object in this case must be able to ensure the husband about the advantage/effectivity of using IUD for their reproduction health (not affecting the system of the body thoroughly, breast milk production, and body fertility can be refreshed quickly), and vice versa, the husband must know about IUD until the agreement in choosing MKJP especially IUD can be achieved. 


\subsubsection{The correlation of culture and the usage of contraception MKJP especially IUD}

The research results found out that out of 122 respondents having bad culture, in fact 120 respondents (98.4\%) do not use MKJP especially IUD. Out of 121 respondents having good culture, in fact 111 respondents (91.7\%) do not use MKJP especially IUD. The result of statistical chi-square test obtained $p=0.013<0.05$, it means there is correlation between culture and the usage of MKJP especially IUD at Society Health Center Simpang Baru. It also obtained the score of OR in the amount of 5.41 which means respondents with bad culture have a chance 5.41 times higher to not using contraception MKJP especially IUD compared to those with good culture.

Culture forbids or does not forbid because of the issue in the society about the side effect of AKDR usage which is bleeding takes long time and it disturbs the worship of someone [4]. The habit in the society in line with technology and information developing nowadays has big effect in changing the habit considered beneficial. The religious value is also an important part from the value of the group culture in having a dominant culture affecting many aspects of life, one of them is family planning (KB).

The result of this research is in line with the research about the factors related to contraception tool in the womb (AKDR) for KB acceptors at Society Health Center Jailolo. Those factors are ages, education, knowledge, service fee, the spouse agreement, culture with choosing AKDR at Society Health Center Jailolo. While the occupation, economy, and service fare do not have correlation to the usage of AKDR. Education is the most dominant factor in choosing AKDR [4]. Furthermore, the result of this research is also in line with another research that found out that the factors correlate to the usage of AKDR are socio-demography, cultural factor, access factor towards the service, and socio psychological factor with the usage of AKDR. The cultural factor is the most dominant factor [6].

According to researchers' assumption, culture is a complexity of life design created historically either implicitly or explicitly, rasionality which emerges belief, and the capability to be learnt in the society. Therefore, the approaches to the scholar, public figures, and sinergy across secotrs are extremely necessary that the usage of MKJP do not disturb someone's worship. Sinergy among the medical staff and the candidates must be intertwined well and continuously until the society believe and willing to use MKJP especially IUD. 


\section{Conclusion}

1. There is correlation between knowledge and the usage of Long Term Contraception Method (MKJP) especially IUD in the domain of Society Health Center Simpang Baru Pekanbaru city with $p$ value 0.00 .

2. There is correlation between spouse support and and the usage of Long Term Contraception Method (MKJP) especially IUD in the domain of Society Health Center Simpang Baru Pekanbaru city with $\mathrm{p}$ value 0.013 .

3. There is correlation between culture and and the usage of Long Term Contraception Method (MKJP) especially IUD in the domain of Society Health Center Simpang Baru Pekanbaru city with $\mathrm{p}$ value 0.019 .

4. It is expected that the results of this research can be the input for improving the usage scope of MKJP especially IUD at Society Health Center particularly and in Pekanbaru City in general through giving information as much as possible about MKJP especially IUD, increasing the knowledge of fertile age couples through socialization, leaflet, and other media and activating the agent in the field, effective communication among spouses, and approach to the scholar, and public figures and creating the new culture using IUD as the contraception tool.

\section{Funding}

This research was funded by lecturer research grant from The Ministry of Research, Technology, and Higher Education (Kemenristekdikti) No. 070/K10/KM/KONTRAKPENELITIAN/2018

\section{Acknowledgement}

The writer would like to thank all stakeholders that had given the contribution, suggestion, criticism, and assistance in making this research perfect.

\section{Conflict and Interest}

The writer does not have conflict and interest to publish the this research. 


\section{References}

[1] Biro Pusat Statistik, Survei demografi dan kesehatan:Pola Kontrasepsi di Indonesia, Jakarta: BPS SDKI, 2012.

[2] BKKBN Propinsi Riau, 2008, Keluarga Berencana, Kesehatan Reproduksi, Gender dan pembangunan Kependudukan, Riau:BKKBN

[3] Notoatmodjo,2003, IImu Kesehatan Masyarakat.Jakarta.Rineka Cipta

[4] Bernandus dkk (2013),Faktor-faktor yang berhubungan dengan penggunaan alat kontrasepsi dalam rahim (AKDR) bagi akseptor KB di Puskesmas Jailolo,Artikel,PSIK UNHAS2 2013

[5] Wardani (2011), Faktor-faktor yang berhubungan dengan kepesertaan KB oleh PUS di wilayah kerja Puskesmas Tambang Kabupaten Kampar tahun 2011

[6] Setiowati (2008), Faktor-faktor yang berhubungan dengan penggunaan alat kontrasepsi dalam rahim pada akseptor KB golongan risiko tinggi di Puskesmas Wilayah Kec.Cimahi Selatan Kota Cimahi Tahun 2008 